\title{
Review
}

\section{Political uses of Utopia: New Marxist, anarchist, and radical democratic perspectives}

\author{
S. D. Chrostowska and James D. Ingram (Eds.) \\ New York, Columbia University Press, 2016, 331 pp., \\ ISBN: 9780231179591
}

Contemporary Political Theory (2020) 19, S75-S78. https://doi.org/10.1057/s41296018-00287-8; published online 27 November 2018

Political uses of Utopia: New Marxist, anarchist, and radical democratic perspectives, edited by Chrostowska and Ingram, is an excellent volume on the relation between utopianism, political thought, and real politics. Its thirteen chapters, flanked by an introduction and a finishing coda, divide into four parts. The first part consists of three essays (by Miguel Abensour, Richard Saage, and Francisco Fernández Buey) reassessing the history and political role of utopian political theorising, each of which argues - in different ways - that utopian political thought has been (and still can be) more valuable and important than is often believed. Abensour's translated essay (originally published in two parts in 1973 and 1974) shows the often-unrecognised depth of Marx and Engels' engagement with utopian socialism and the growth of reflexivity and self-critical capacity within utopian socialism itself. Saage's wide-ranging essay (originally published in 2004) argues that classical utopian theorising is often more insightful and politically powerful than its contemporary variants, while the excerpts from Buey's writings draw lessons from various classical utopian texts to the challenges faced by the modern world.

Part 2 contains four discussions (by Franck Fischbach, Peter Hallward, Étienne Balibar, and John Grant) of the relationship between utopianism and perhaps its most prominent critic, Marxism. Fischbach's contribution explores Marx and Engels' engagement with utopian theorising, arguing that a Marxist utopianism must be a negative one. Hallward's chapter draws on Rousseau and Marx to argue that transformative politics requires not only utopian wishing, but also the revolutionary will to make it a reality, with some reflections on what this entails. Balibar's chapter argues that utopianism has been rendered obsolete by recent changes in society and that this requires a re-orientation of political thought from thinking about other possible worlds and how to get from here to there to thinking

(c) 2018 Springer Nature Limited. 1470-8914 Contemporary Political Theory Vol. 19, S1, S75-S78 
about transforming the existing world from the inside. Finally, Grant's chapter criticises Fredric Jameson's attempt at marrying Marxism and utopianism.

The essays in part 3 (by Michèle Riot-Sarcey, Michaël Löwy, and Ruth Kinna) discuss the relationship between utopianism and social and political movements, while those in part 4 (by Jacques Rancière, Raymond Geuss, and Étienne Tassin) analyse different political elements in utopian thinking. Riot-Sarcey's chapter explores the role of utopian theorising in women's and workers' movements; Löwy's the utopian theorising of the global justice movement, and Kinna's the role of utopianism in anarchist political thought - the two latter will be discussed further below. Rancière argues that utopian desire can help to open politics up for greater emancipatory possibilities, while Tassin shows how utopian fiction has an important role to play in democratic theory. Finally, Geuss's essay argues persuasively that realism in political theory is not opposed to utopianism, but rather to ideology and wishful thinking. Once this distinction is made, we can see why he charges Rawlsian political theory for being both insufficiently utopian (because it takes the basic institutions of the United States in the second half of the 20th Century largely as given) and insufficiently realistic (because this social reality appears in 'a peculiarly distorted form, cleansed of all power phenomena and distorted by wishful thinking' (p. 246)).

Much current work on utopianism remains trapped between abstract and moralist Rawlsian attempts at creating 'real utopias', heavily normative visions of what perfect sets of political principles and institutions would be like, or Eric Olin Wright-type explorations of 'real utopias' that look to existing practices which are not (yet) widespread on large scales. However, both the classical utopian texts and utopian theorising outside of the academy are much richer and more varied, but sadly largely elided by political theorists. One of the major strengths of this book is that it draws attention to and explores these (in political theory) neglected areas. I will not attempt the impossible task of doing justice to all the contributions in this volume - from Abensour's important discussion of the complexities of Marx and Engels' dialogue with utopian theorists to Geuss' incisive reflections of the realism, utopianism, and wishful thinking. Instead, I will focus on a handful of contributions touching on the oft-neglected question of the value of utopian theorising for social and political movements. This question is particularly important today, as radical movements are increasingly asking questions about which institutions are required for a more free, equal, and democratic alternative to capitalism and what we can do to transition to them.

There is currently (fairly) widespread support - from the later Rawls to critical theory - for various versions of context-dependent political theory, seeking to reconstruct the values that are appropriately internal to existing institutions and practices. One of the general concerns about this is how, if at all, such an approach can be used to criticise not only dominant institutions and practices, but also dominant ethical and political values themselves. One suggestion for how to do this 
is to examine the political practices of marginalised and disadvantaged groups contesting the legitimacy of existing institutions and the values implicit therein. Interestingly, this is what Michael Löwy does in his chapter on 'Negativity and Utopia in the Global Justice Movement'. Perhaps the largest worldwide mass movement of recent years (especially in the global south), the global justice movement contains what he calls a 'utopian dimension' that includes 'dreaming and fighting for another civilization, another economic and social paradigm, and another form of living together on this planet' (p. 194). These include (a) the humanist ideal that society be re-organised around the real needs and aspirations of human beings themselves; (b) an ideal of democracy that involves the real participation, decision-making, and control; reconfigured notions of (c) liberty, (d) equality, and (e) (not fraternity but) solidarity; and (f) a diversity of different forms of life - in the words of the Zapatistas, a 'world in which many worlds have their place' (p. 196). This is a utopian transvaluation carried out not from the philosophical armchair, but from bottom-up movements articulating their emerging ideals. It should remind us of the role such movements have played for political theory in the past, when, e.g. the Levellers changed the landscape of political thought in ways that a new generation of thinkers - from Hobbes to Locke to Spinoza - had to respond to.

From this discussion of utopian political values, I turn to a discussion of utopian visions of future institutions and societies in Franck Fischbach's chapter on 'Marx and Utopia'. Here of course it is important to recall that Marx's critique is much more specific than most discussions of utopianism tend to be: his target was not generally 'utopians' or 'utopianism' as such, but instead a specific group of thinkers labelled the 'utopian socialists' - especially Charles Fourier, Henri Saint-Simon, and Robert Owen. The reader will recall that Marx, in the Communist Manifesto, offers three main criticisms of utopian socialism: (i) they fail to properly investigate and understand the political agency required to bring about the society they want. As a result of this failure, they seek to appeal to wealthy capitalists for support, thinking that their wealth will help them begin to construct a new socialist society right away. This leads them to (ii) act in ways which are not really conducive to reaching their goals (i.e. appealing to the generosity of the powerful and privileged to bring about socialism), and (iii) end up working against the only form of agency that could reach their goals - working class struggle - due to its incompatibility with successfully appealing to capitalists for financial and other support.

Marx and Engels' critique, however, as Fischbach points out, is less a critique of utopian blueprints as such than a critique of those who are not properly rooted in the proletarian movement - that is, in the political agency it ought to be part of. Acknowledging the unpredictable power of human creativity, Marx and Engels sought to uncover 'tendencies already at work in the present' within capitalism which, 'insofar as they are taken up in political practice, can become conditions for

(c) 2018 Springer Nature Limited. 1470-8914 Contemporary Political Theory $\quad$ Vol. 19, S1, S75-S78 $\quad$ S77 
the impossibility of capitalism' (pp. 121-122). Accordingly, he argues, any Marxian conception of utopia must be a negative one: referring to "what in the present social space constitutes a negation of the work of the current order of things' (p. 122).

I think it is possible to go beyond this, though I cannot pursue this argument indepth here. Several Marxist and anarchist thinkers like Anton Pannekoek and Peter Kropotkin have argued that the careful study of on-going social processes especially social movements - can be used to explore what sort of future society they are likely to push towards, and how they can maximise their chances of success. The latter is particularly important today in growing debates within anarchism, Marxism, and even for academics concerned with prefigurative politics: how should current organisations deliberately implement desired future social relations and practices in the here-and-now? It is hard to make sense of such a commitment absent any conception of what a desirable future would be like, the subject of Ruth Kinna's chapter on 'Utopianism and Prefiguration'.

Kinna's chapter explores the relation between utopianism and prefigurative politics with reference to Occupy and its precursors, drawing especially on Benjamin Franks' influential work. While there is a utopian strain in anarchism, she argues, it tends to reject the scientistic, historicist, and instrumental ways of construing the means-ends relation that many associate with it. Anarchists invoke utopia 'to assert the possibility of different alternatives' and 'elaborated strategies for change consistent with their antiauthoritarian principles precisely in order to resist unspecified abstract utopias or blueprints' (p. 208).

Each of the chapters I have discussed here looks at utopianism's relation not just with political theory, but also with real politics. Given the current crisis of capitalism and growing support for socialism worldwide, more and more people are asking and thinking about what the alternatives to it might be. This is likely why we are seeing growing speculation and debate about alternative economic institutions, which are invariably utopian in at least one or more of its many guises. This raises a host of questions about the value of such utopias and their role, if any, in relation to social and political movements seeking to replace capitalism with more free, equal, and democratic form of life and society. Of all the recent academic collections on utopia and utopianism, this is the best place to start looking for answers.

Paul Raekstad

University of Amsterdam, 1001 NB Amsterdam, The Netherlands paul.raekstad@cantab.net 